\title{
BMJ Open Cross-sectional survey of the amount of sugar and energy in cakes and biscuits on sale in the UK for the evaluation of the sugar-reduction programme
}

Kawther M Hashem, Feng J He, Sarah A Alderton, Graham A MacGregor

To cite: Hashem KM, He FJ, Alderton SA, et al. Crosssectional survey of the amount of sugar and energy in cakes and biscuits on sale in the UK for the evaluation of the sugar-reduction programme. BMJ Open 2018;8:e019075. doi:10.1136/ bmjopen-2017-019075

- Prepublication history and additional material for this paper are available online. To view these files, please visit the journal online (http://dx.doi org/10.1136/bmjopen-2017019075).

Received 10 August 2017 Revised 24 November 2017 Accepted 12 December 2017

Check for updates

Wolfson Institute of Preventive Medicine, Barts and The London School of Medicine and Dentistry, Queen Mary University of London, London, UK

Correspondence to Kawther M Hashem; k.hashem@qmul.ac.uk

\section{ABSTRACT}

Objectives To investigate the variation in sugar and energy content of cakes and biscuits available in the UK. Design We carried out a cross-sectional survey in 2016 of 381 cakes and 481 biscuits available in nine main UK supermarkets.

Methods The sugar and energy content was collected from product packaging and nutrition labelling of cake and biscuit products.

Results The average sugar content in cakes and biscuits was $36.6 \pm 7.6$ and $30.0 \pm 9.2 \mathrm{~g} / 100 \mathrm{~g}$, respectively. The mean energy content was $406 \pm 37$ for cakes and $484 \pm 38$ $\mathrm{kcal} / 100 \mathrm{~g}$ for biscuits. There was a large variation in sugar and energy content between different cake and biscuit categories and within the same category. $97 \%$ of cakes and $74 \%$ of biscuits would receive a 'red' (high) label for sugar.

Conclusions This research makes available baseline data of the cakes and biscuits market in the UK for future evaluation of the recently launched sugarreduction programme. The study showed that reductions in sugar and energy content of cakes and biscuits are possible, since there was a large variation in sugar and energy content between different cake and biscuit categories and within the same category. A reduction in sugar and energy content, and overall cake and biscuit consumption, can help reduce overall sugar and energy intake in the UK and thus reduce the risk of obesity and dental caries.

\section{INTRODUCTION}

In July 2015, a new free sugars (sugar) recommendation was announced by the Scientific Advisory Committee on Nutrition due to the link between excess sugar intake and obesity, type 2 diabetes and dental caries risk, ${ }^{1-7}$ which are all major public health problems in the $\mathrm{UK},{ }^{8-14}$ and contribute to significant healthcare costs. ${ }^{15}$ Free sugars includes all monosaccharides and disaccharides added to foods by the manufacturer, cook or consumer, plus sugars naturally present in honey, syrups and unsweetened fruit juices and excludes lactose when naturally present in milk and milk products, as well as sugars contained within the

\section{Strengths and limitations of this study}

- This paper for the first time investigates and documents the sugar and energy content of cakes and biscuits sold in the UK.

- The results demonstrate that the amount of sugar and energy can be reduced, since there was a wide variation in sugar and energy content between different categories of cakes and biscuits, as well as within the same category.

- This study was based on the amount of sugar and energy provided on product nutrition labelling instore; hence, we relied on the accuracy of the data provided on the label.

cellular structure of foods (ie, whole fruits and vegetables). ${ }^{16}$

In 2014, average intakes of sugar exceeded the UK recommendations (less than $5 \%$ of energy intake) in all age groups. The average sugar intake in adults is $60 \mathrm{~g} /$ day, which is equivalent to $240 \mathrm{kcals}$ and contributes to $12 \%$ of energy intake. Some children have a higher sugar intake, 54 and $73 \mathrm{~g} /$ day in 4-10 and $11-18$ year-olds, respectively. ${ }^{17}$ This is likely to be an underestimate of how much sugar they actually consume ${ }^{18} 19$ because under-reporting consumption of high-sugar foods and drinks is highly prevalent in surveys that rely on self-reported data. ${ }^{20-23}$

The UK government recently announced in its Childhood Obesity: A Plan for Action (2016) a sugar-reduction programme, where it is asking manufacturers to reduce sugar by $20 \%$ by 2020 in each of the nine categories of food and drink that contribute most to sugar intake in children's diets. Cakes, morning goods (eg, croissants) and biscuits are main contributors of sugar intake in children (4-10 years), teenagers (11-18 years) and adults (18-64 years), contributing to $9 \%, 9 \%$ and $7 \%$ of sugar intake, respectively. ${ }^{17}$ 
Table 1 Description and examples of cake categories

\begin{tabular}{|c|c|}
\hline Category & Description and examples \\
\hline Almond & Products described as almond fingers or almond slices. \\
\hline Angel & Products described as 'Angel' cake or 'Angel' slices. \\
\hline Bakewell & Products described as 'Bakewell' slices. \\
\hline Battenberg & Products described as 'Battenberg'. \\
\hline Blueberry muffins & Products described as blueberry muffins, including mini size. \\
\hline Brownies & Products described as brownies, excluding flavoured brownies. \\
\hline Carrot & Products described as carrot cake, excluding flavoured carrot cake, for example, fudge carrot cake. \\
\hline Chocolate & Products described as chocolate cake or similar, including chocolate birthday/celebration cakes. \\
\hline Chocolate cake bar & Products described as chocolate cake bar, including caramel flavoured. \\
\hline Chocolate muffins & $\begin{array}{l}\text { Products described as chocolate muffins, including 'chocolate chip' and 'double chocolate' and sold in } \\
\text { regular or mini size. }\end{array}$ \\
\hline Chocolate Swiss roll & Products described as 'Chocolate Swiss roll' or chocolate roll or sponge roll and sold in regular or mini size. \\
\hline Coconut & Products described as coconut cake or similar. \\
\hline Coffee and walnut & Products described as coffee and walnut cake or similar. \\
\hline Coffee & Products described as coffee cake, iced or containing buttercream. \\
\hline Cupcake/fairy cakes & Products described as cupcake and 'Fairy Cake' and do not fit in any other category. \\
\hline Fruit & Products described as fruit cake or similar, including iced varieties. \\
\hline Genoa & Products described as 'Genoa'. \\
\hline Fruit Swiss roll & $\begin{array}{l}\text { Products described as 'Swiss roll' and fruit flavoured, for example, Raspberry Swiss Roll, in regular or mini } \\
\text { size. }\end{array}$ \\
\hline Ginger & Products described as ginger cake or bun. \\
\hline Lemon & Products described as lemon cake or similar, for example, lemon and poppy seed loaf cake. \\
\hline Lemon Swiss roll & Products described as 'Lemon Swiss Roll' or similar. \\
\hline Madeira & Products described as 'Madeira Cake' and plain. \\
\hline Fruited Madeira & Products described as 'Madeira Cake' with fruit. \\
\hline Iced Madeira & Products described as 'Madeira Cake', iced and of any flavour. \\
\hline Red velvet & Products described as 'red velvet', including cupcake varieties. \\
\hline Victoria & Products described as 'Victoria sponge' or similar. \\
\hline Walnut & Products described as walnut cake. \\
\hline White chocolate & Products described as white chocolate cake and filled with strawberry or raspberry jam. \\
\hline Plain with chocolate & Plain sponge topped with chocolate or containing chocolate chips. \\
\hline
\end{tabular}

Manufacturers can choose to achieve the $20 \%$ reduction in a number of ways: by reformulating their products (without increasing overall calories), reducing portion size or promoting their lower-sugar products. The main aim is to gradually reduce the amount of added sugar until 2020. ${ }^{24}$ Sales weighted averages (SWA) address the most popular products on the market and were used to set category-specific sugar-reduction targets per $100 \mathrm{~g}$ of a product. SWA for cakes is currently $34.9 \mathrm{~g}$, with the aim of bringing it down to $27.9 \mathrm{~g}$ per $100 \mathrm{~g}$ by $2020 .^{24}$ For biscuits, the SWA is $32.8 \mathrm{~g}$ to be reduced to $26.2 \mathrm{~g}$ per $100 \mathrm{~g} .{ }^{24}$ The SWA allows for flexibility in the levels of sugar in different products within a category, for example, a biscuit manufacturer can continue to sell a high-sugar biscuit if the remainder of their portfolio is lower, however if the high-sugar product is a big seller, the amount of sugar will have to be reduced through reformulation, smaller portions, or price promotions will have to be removed to reduce the overall sale. ${ }^{24}$ Calorie caps for single-serve cakes and biscuits are set at a maximum of 325 kcal. $^{24}$

Traditionally, cakes were considered treats for special occasions, such as birthdays, but now only 3 in 10 people buy cakes for this reason. ${ }^{25}$ Cakes are consumed more frequently, and the market is changing with the rise in small cakes. The volume sales of small cakes have been growing substantially and has now overtaken large cakes, with a market share of $44 \%$ and $37 \%$, respectively. ${ }^{26}$ These cakes are likely to be consumed as regular snacks, contributing to the increase in sugar intake. ${ }^{17}$

Biscuits are also widely consumed in the UK; 9 in 10 adults eat sweet biscuits regularly, with $55 \%$ of people eating them at least once a week. ${ }^{27} \mathrm{~A}$ Mintel report published in 2015 estimated that values sales in the market would grow by $4 \%$ by $2019 .{ }^{27}$ Biscuits are not often viewed as a 'treat' like chocolate and desserts. Instead they may 
Table 2 Description and examples of biscuit categories

\begin{tabular}{|c|c|}
\hline Category & Description and examples \\
\hline Bourbon & Products described as 'Bourbon' or similar. \\
\hline Custard cream & Products described as ‘custard cream' or similar. \\
\hline Jam filled & Biscuits filled with jam only, for example, Jammie Dodgers and Aldi Belmont Biscuits Jammy Wheels. \\
\hline Jam and cream & Biscuits with jam and cream filling, for example, Viennese Whirl. \\
\hline Fruit filled & $\begin{array}{l}\text { Biscuits with fruit filling, including yoghurt coated, for example, Go Ahead! Crispy Slices Orange and } \\
\text { Garibaldi Biscuits. }\end{array}$ \\
\hline Breakfast unfilled & Products described as breakfast biscuits and contain no filling. \\
\hline Breakfast filled & Products described as breakfast biscuits with filling, for example, Belvita Breakfast Yoghurt. \\
\hline Chocolate chip & Products described as cookies or biscuit containing dark, milk or white chocolate chips or chunks. \\
\hline $\begin{array}{l}\text { Chocolate-coated } \\
\text { ginger }\end{array}$ & Products described as ginger biscuits and chocolate coated. \\
\hline Chocolate digestives & Products described as 'digestives' and chocolate coated. \\
\hline Digestives & Products described as 'digestives' and plain. \\
\hline Ginger stem & Products described as cookies or biscuits with ginger stem or similar. \\
\hline Ginger & Products described as ginger-flavoured biscuit and plain, for example, Ginger Nuts. \\
\hline Iced & Biscuits topped with icing and plain, for example, Fox's Party Rings and McVitie's Iced Gems \\
\hline Malted milk & Products described as malted milk or similar and plain. \\
\hline Nice & Products described as 'Nice' or similar and plain. \\
\hline Oatmeal & Biscuits made of oatmeal or oats and plain, for example, McVitie's Hobnobs. \\
\hline Rich Tea & Products described as ‘Rich Tea' or similar and plain. \\
\hline Shortbread & Products described as shortbread or similar and plain. \\
\hline $\begin{array}{l}\text { Shortbread with } \\
\text { additions or coated }\end{array}$ & $\begin{array}{l}\text { Products described as shortbread with additions, for example, Marks \& Spencer Scottish All Butter } \\
\text { Choc Chunk Shortbread Rounds and Asda Extra Special Stem Ginger Shortbread Thins. }\end{array}$ \\
\hline Flavoured shortbread & $\begin{array}{l}\text { Biscuits described as shortbread with flavouring, for example, Asda Extra Special Lemon Shortbread } \\
\text { Thins and Waitrose Seriously Delicate All butter Rose Shortbread. }\end{array}$ \\
\hline Shortcake & Products described as shortcake or similar and plain. \\
\hline Wafer & Products described as wafer or similar, for example, Thorntons Double Chocolate Wafer Rolls. \\
\hline
\end{tabular}

be consumed as a regular staple with a hot drink, and therefore contribute to excess sugar intake. ${ }^{27}$

Supermarket own label products dominate the cake market in the UK, equating to $56 \%$ of shares by value. ${ }^{25}$ Premier Foods manufactures the two biggest brands on the market, Mr Kipling and Cadbury cakes, with $15 \%$ and $6 \%$ of shares by value, respectively. ${ }^{25}$ In 2014-2015, the biscuit market was dominated by United Biscuits (26\%), own label products $(23 \%)$ and Mondelez International $(11 \%)$ by value share. ${ }^{27}$

The purpose of this study was to document the levels of sugar and energy in cakes and biscuits in the UK as the data available are generally owned by commercial companies and not in the public domain for comparison and monitoring. This research aims to (a) evaluate the sugar and energy content listed on the labels of cakes and biscuits sold in the UK, (b) report the variability in sugar and energy content, (c) assess the sugar content in relation to the UK's new daily recommendation for sugar intake and by cake and biscuit manufacturers in the UK and (d) compare current serving sizes with the maximum calorie cap of $325 \mathrm{kcal}$ suggested in the sugar-reduction programme.

\section{METHODS}

The data were collected from product packaging and nutrition labelling in 2016. The survey was designed as a comprehensive survey of all cake and biscuit products available in a snapshot in time, using one large outlet per each of the nine main supermarkets.

\section{Data collection}

For each cake and biscuit, the data collected included the company name, brand name, product name, pack weight, serving size, total sugars ( $\mathrm{g}$ ) and energy (kcal) content per $100 \mathrm{~g}$ as well as per suggested serving size. All data were double-checked after entry, and a further $5 \%$ of entries were checked against the original source in a random selection of products.

Data on total energy content was collected since it encompasses the fat, carbohydrate, protein and sugar content of products.

\section{Stores}

Data were collected from each of the major UK supermarkets (Aldi, ASDA, Lidl, Marks and Spencer, Morrisons, Sainsbury's, Tesco, The Co-operative and Waitrose) 


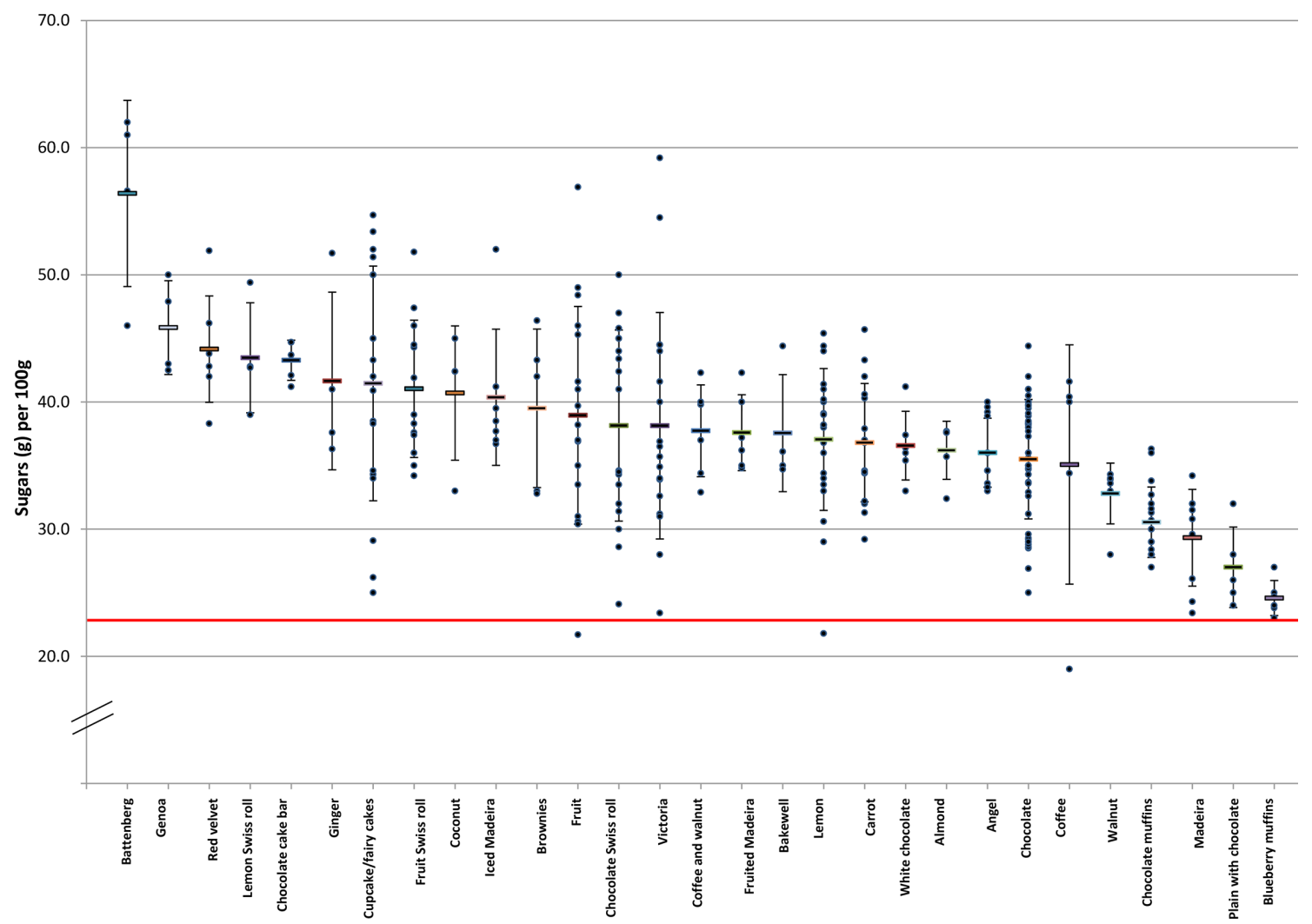

Figure 1 Sugar content in different cake categories $(\mathrm{g} / 100 \mathrm{~g})$, red line denotes the red (high) label criteria for sugar $(>22.5 \mathrm{~g})$.

as these supermarkets collectively hold over $93.2 \%$ of the grocery market share. ${ }^{28}$

\section{Product categories}

Only products with similar formulation/product description were categorised together (tables 1 and 2). Any uncategorised products contributed to the all products data reported. The products were also categorised separately into supermarket own label and branded. Some product categories were excluded from the study (online supplementary file 1).

\section{Inclusion/exclusion criteria}

We included own label and branded cake and biscuit products. We excluded products without nutrition information labelling, such as in-store self-serve bakery items.

\section{Analysis}

Per $100 \mathrm{~g}$ : Some brands sell the same formulation in different serving sizes. The $100 \mathrm{~g}$ data only included an example of one formulation regardless of the different serving sizes.

Per serving: The per-serving data included all the different sugar and energy content available per suggested serving size, or per pack size $\geq 10 \mathrm{~g}$ or $<150 \mathrm{~g}$ for cakes and $\geq 10 \mathrm{~g}$ or $<90 \mathrm{~g}$ for biscuits.

High, medium and low criteria for sugar content: The sugar content was compared with the UK front-of-pack colour-coded labelling for foods: sugars-red/high $>27 \mathrm{~g} /$ portion or $>22.5 \mathrm{~g} / 100 \mathrm{~g}$, amber $/$ medium $>5.0$ and $\leq 22.5 \mathrm{~g} / 100 \mathrm{~g}$, green $/ \mathrm{low} \leq 5.0 \mathrm{~g} / 100 \mathrm{~g}^{29}$
Maximum sugar intake: The sugar content was also compared with the maximum daily recommendation for sugar intake ( $30 \mathrm{~g}$ for adults and $19 \mathrm{~g}$ for $4-6$ year-olds). ${ }^{16}$

Calorie cap: The energy content per serving was compared with the maximum calorie cap of $325 \mathrm{kcal}$ suggested in the sugar-reduction programme. ${ }^{30}$

Manufacturer: The sugar and energy content was compared between manufacturers, where a manufacturer had five or more products in the sample.

\section{STATISTICAL ANALYSIS}

\section{Comparison among products}

Independent Samples t-test was used to compare the levels of sugar and energy between supermarket own label and branded products.

Data are reported as mean, SD and range as indicated. Significance in all tests carried out was deemed as being $p<0.05$. The data was analysed using SPSS software V.22.

\section{RESULTS}

\section{Cakes}

Nutrition information was collected for 381 products.

\section{Sugars}

Figure 1 and table 3 show the sugar content in different categories of cakes per $100 \mathrm{~g}$. A total of 381 products were included in the per $100 \mathrm{~g}$ analysis. The 
Table 3 Sugar and energy content in cakes per $100 \mathrm{~g}$

\begin{tabular}{|c|c|c|c|c|c|}
\hline Category & $\mathbf{n}$ & Sugars (g), mean \pm SD (range) & Category & $\mathbf{n}$ & Energy (kcal), mean \pm SD (range) \\
\hline Own label & 290 & $36.3 \pm 7.4(11.3-61.0)$ & Own label & 290 & $404 \pm 35(273-502)$ \\
\hline Branded & 91 & $37.7 \pm 8.4(19.2-62.0)$ & Branded & 91 & $414 \pm 42(288-500)$ \\
\hline \multicolumn{6}{|l|}{ Descending order } \\
\hline Battenberg & 4 & $56.4 \pm 7.3(46.0-62.0)$ & Plain with chocolate & 5 & $446 \pm 16(421-457)$ \\
\hline Genoa & 4 & $45.9 \pm 3.7(42.5-50.0)$ & Chocolate cake bar & 5 & $445 \pm 41(376-484)$ \\
\hline Red velvet & 7 & $44.2 \pm 4.2(38.3-51.9)$ & Cupcake/fairy cakes & 19 & $440 \pm 41(380-502)$ \\
\hline Lemon Swiss roll & 4 & $43.5 \pm 4.3(39.0-49.4)$ & Coffee and walnut & 6 & $433 \pm 22(403-460)$ \\
\hline Chocolate cake bar & 5 & $43.3 \pm 1.6(41.2-44.7)$ & Red velvet & 7 & $433 \pm 27(411-489)$ \\
\hline Ginger & 4 & $41.7 \pm 7.0(36.3-51.7)$ & Chocolate & 42 & $430 \pm 21(365-475)$ \\
\hline Cupcake/fairy cakes & 19 & $41.5 \pm 9.2(25.0-54.7)$ & Brownies & 5 & $430 \pm 23(406-454)$ \\
\hline Fruit Swiss roll & 13 & $41.0 \pm 5.4(34.2-51.8)$ & White Chocolate & 6 & $423 \pm 12(402-436)$ \\
\hline Coconut & 4 & $40.7 \pm 5.3(33.0-45.0)$ & Chocolate Swiss roll & 18 & $420 \pm 36(366-500)$ \\
\hline Iced Madeira & 7 & $40.4 \pm 5.4(36.7-52.0)$ & Chocolate muffins & 18 & $416 \pm 21(369-475)$ \\
\hline Brownies & 5 & $39.5 \pm 6.2(32.8-46.4)$ & Coconut & 4 & $416 \pm 36(394-470)$ \\
\hline Fruit & 17 & $39.0 \pm 8.6(21.7-56.9)$ & Walnut & 6 & $405 \pm 11(395-426)$ \\
\hline Chocolate Swiss roll & 18 & $38.1 \pm 7.5(24.1-50.0)$ & Iced Madeira & 7 & $405 \pm 20(391-445)$ \\
\hline Victoria & 18 & $38.1 \pm 8.9(23.4-59.2)$ & Coffee & 5 & $403 \pm 19(391-435)$ \\
\hline Coffee and walnut & 6 & $37.7 \pm 3.6(32.9-42.3)$ & Victoria & 18 & $402 \pm 36(346-456)$ \\
\hline Fruited Madeira & 6 & $37.6 \pm 3.0(34.8-42.3)$ & Battenberg & 4 & $401 \pm 22(375-421)$ \\
\hline Bakewell & 4 & $37.6 \pm 4.6(34.7-44.4)$ & Angel & 12 & $398 \pm 16(378-420)$ \\
\hline Lemon & 21 & $37.0 \pm 5.6(21.8-45.4)$ & Bakewell & 4 & $397 \pm 41(335-422)$ \\
\hline Carrot & 16 & $36.8 \pm 4.7(29.2-45.7)$ & Almond & 5 & $396 \pm 16(379-411)$ \\
\hline White chocolate & 6 & $36.6 \pm 2.7(33.0-41.2)$ & Lemon & 21 & $394 \pm 22(358-439)$ \\
\hline Almond & 5 & $36.2 \pm 2.3(32.4-37.7)$ & Carrot & 16 & $389 \pm 20(323-415)$ \\
\hline Angel & 12 & $36.0 \pm 2.7(33.0-40.0)$ & Madeira & 9 & $387 \pm 9(367-395)$ \\
\hline Chocolate & 42 & $35.5 \pm 4.7(25.0-44.4)$ & Ginger & 4 & $383 \pm 20(362-406)$ \\
\hline Coffee & 5 & $35.1 \pm 9.4(19.0-41.6)$ & Fruited Madeira & 6 & $380 \pm 51(347-484)$ \\
\hline Walnut & 6 & $32.8 \pm 2.4(28.0-34.3)$ & Blueberry muffins & 6 & $378 \pm 28(331-408)$ \\
\hline Chocolate muffins & 18 & $30.5 \pm 2.8(27.0-36.3)$ & Lemon Swiss roll & 4 & $375 \pm 34(349-425)$ \\
\hline Madeira & 9 & $29.3 \pm 3.8(23.4-34.2)$ & Fruit & 17 & $367 \pm 39(273-449)$ \\
\hline Plain with chocolate & 5 & $27.0 \pm 3.2(24.0-32.0)$ & Fruit Swiss roll & 13 & $365 \pm 36(301-422)$ \\
\hline Blueberry muffins & 6 & $24.6 \pm 1.4(23.0-27.0)$ & Genoa & 4 & $356 \pm 16(344-380)$ \\
\hline All products & 381 & $36.6 \pm 7.6(11.3-62.0)$ & All products & 381 & $406 \pm 37(273-502)$ \\
\hline
\end{tabular}

average sugar content in cakes was $36.6 \pm 7.6 \mathrm{~g} / 100 \mathrm{~g}$. There was a large variation in sugar content between different categories of cakes and within the same category of cake (eg, among all chocolate cake products) ranging from 11.3 to $62.0 \mathrm{~g} / 100 \mathrm{~g}$. On average, Battenberg $(56.4 \pm 7.3 \mathrm{~g} / 100 \mathrm{~g})$ contained the highest amounts of sugar, ranging from 46 to $62 \mathrm{~g}$, followed by Genoa $(45.9 \pm 3.7 \mathrm{~g} / 100 \mathrm{~g})$ and red velvet cakes $(44.2 \pm 4.2 \mathrm{~g} / 100 \mathrm{~g})$, while blueberry muffins $(24.6 \pm 1.4 \mathrm{~g} / 100 \mathrm{~g})$ contained the lowest amount of sugar. The high amount of sugar in Genoa cakes is partly due to the added dried fruits. Branded cakes had a slightly higher sugar content per $100 \mathrm{~g}$ compared with supermarket own label ( $37.7 \mathrm{~g}$ vs $36.3 \mathrm{~g}$ ), but the difference was not statistically significant $(\mathrm{p}=0.137)$. Ninety-seven per cent of cakes would receive a 'red' (high) label for sugar (>22.5 g/100 g) (figure 1).

A total of 370 products provided nutrition information per suggested serving size and were included in the per serving analysis (table 4). The mean sugar content in cakes was $16.9 \pm 7.6 \mathrm{~g} / \mathrm{serving}$. Red velvet cakes contained the highest sugar content per serving $(28.2 \pm 9.8 \mathrm{~g}$, almost an adult's entire maximum daily intake for sugar), followed by coffee and walnut cakes $(24.9 \pm 2.8 \mathrm{~g})$.

On average, a serving of cake contains over half of an adult's ( $30 \mathrm{~g} /$ day) and almost all of a 4-6 year-old 
Table 4 Sugar and energy content in cakes per serving

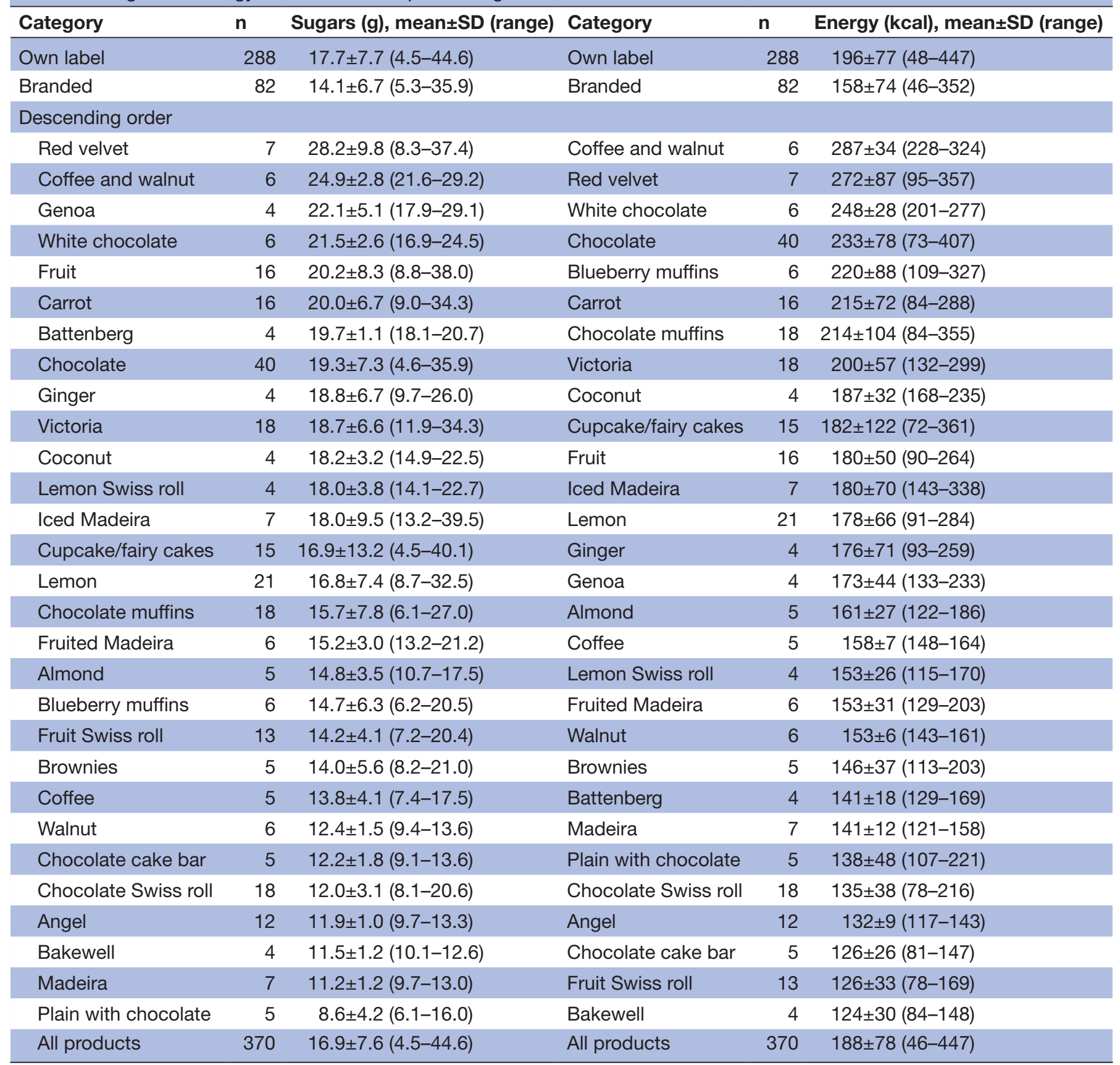

child's (19g/day) maximum daily recommended sugar intake.

\section{Energy}

Figure 2 and table 3 show the energy content in different categories of cakes per $100 \mathrm{~g}$. The average energy content in cakes was $406 \pm 37 \mathrm{kcal} / 100 \mathrm{~g}$. There was a large variation in energy content between different categories of cakes and within the same category of cakes ranging from 273 to $502 \mathrm{kcal} / 100 \mathrm{~g}$. On average, plain sponge with chocolate $(446 \pm 16 \mathrm{kcal} / 100 \mathrm{~g})$ contained the highest amount of energy, ranging from 421 to $457 \mathrm{kcal}$, while Genoa cakes $(356 \pm 16 \mathrm{kcal} / 100 \mathrm{~g})$ contained the lowest amount of energy.

The mean energy content in cakes was $188 \pm 78 \mathrm{kcal} /$ serving. Coffee and walnut cakes contained the highest amount of energy per serving $(287 \pm 34 \mathrm{kcal} /$ serving $)$ and Bakewell (124 $\pm 30 \mathrm{kcal} / \mathrm{serving})$ contained the lowest (table 4). A total of 19 products exceeded the maximum calorie cap of $325 \mathrm{kcal}$ per serving.

Among the manufacturers with five or more cakes, the McVitie's product range contained the highest average sugar $(43.1 \pm 7.3 \mathrm{~g})$ and Premier Foods 


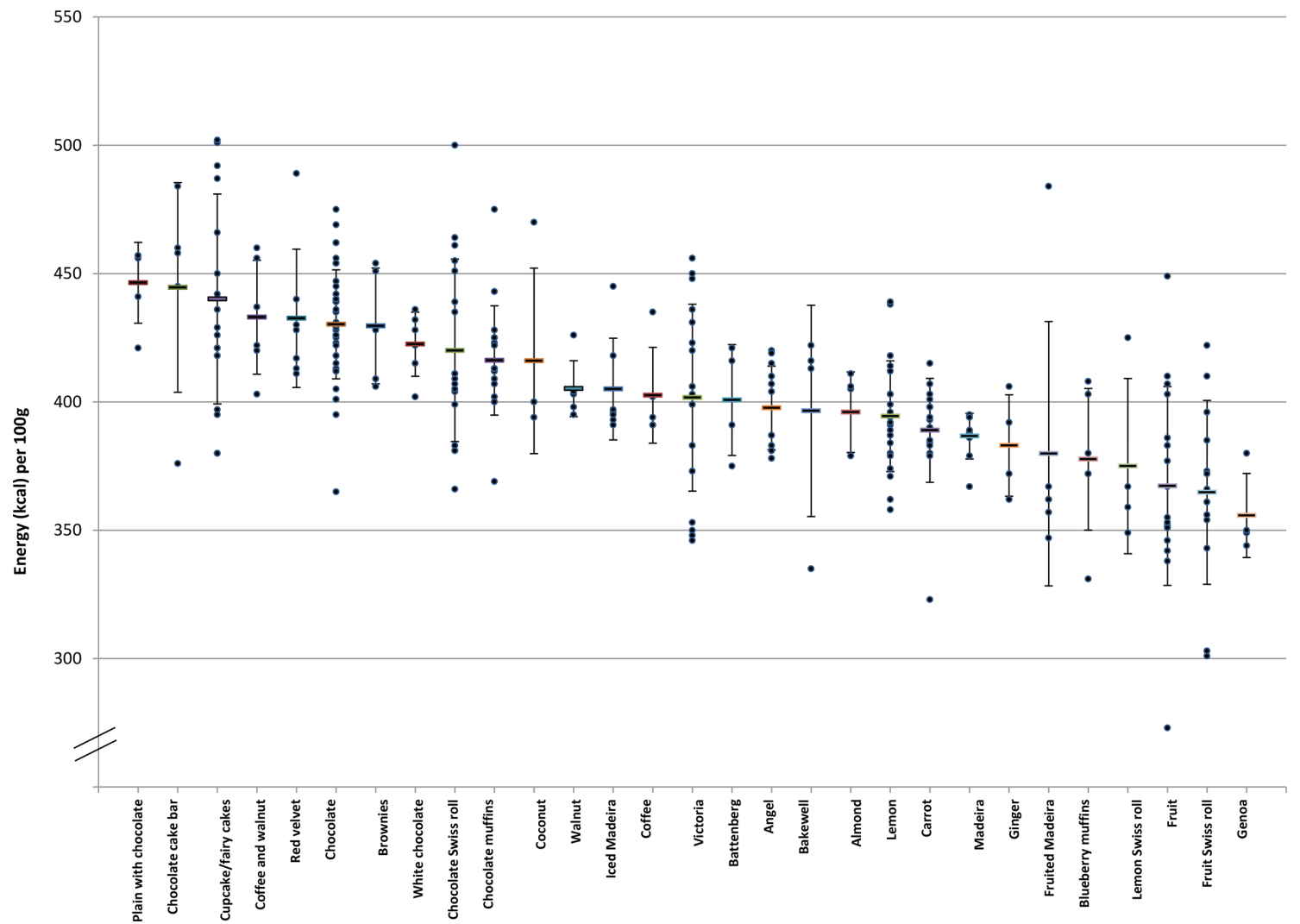

Figure 2 Energy content in different cake categories (kcal/100g).

contained the highest energy $(424 \pm 26 \mathrm{kcal})$ per $100 \mathrm{~g}$ (table 5).

\section{Biscuits}

Nutrition information was collected for a total of 481 biscuit products.

\section{Sugars}

Figure 3 and table 6 show the sugar content in different categories of biscuits per $100 \mathrm{~g}$. A total of 481 products were included in the per $100 \mathrm{~g}$ analysis. The average sugar content in biscuits was $30.0 \pm 9.2 \mathrm{~g} / 100 \mathrm{~g}$. There was a large variation in sugar content between different categories of biscuits and within the same category of biscuits, ranging from 12.0 to $74.0 \mathrm{~g} / 100 \mathrm{~g}$. On average, iced biscuits $(43.5 \pm 6.3 \mathrm{~g} / 100 \mathrm{~g})$ contained the highest amounts of sugar and shortbread biscuits $(17.5 \pm 2.8 \mathrm{~g} / 100 \mathrm{~g})$ contained the lowest. Branded biscuits had a significantly higher sugar content compared

Table 5 Sugar and energy content in cakes by manufacturer per $100 \mathrm{~g}$

\begin{tabular}{|c|c|c|c|c|c|}
\hline Manufacturer & $\mathbf{n}$ & $\begin{array}{l}\text { Sugars (g), mean } \pm S D \\
\text { (range) }\end{array}$ & Manufacturer & $\mathbf{n}$ & $\begin{array}{l}\text { Energy (kcal), mean } \pm S D \\
\text { (range) }\end{array}$ \\
\hline McVitie's & 7 & $43.1 \pm 7.3(36.8-52.5)$ & $\begin{array}{l}\text { Premier Foods } \\
\text { (Cadbury Cakes and } \\
\text { Mr Kipling) }\end{array}$ & 33 & $424 \pm 26(383-492)$ \\
\hline $\begin{array}{l}\text { Premier Foods } \\
\text { (Cadbury Cakes and } \\
\text { Mr Kipling) }\end{array}$ & 33 & $39.7 \pm 6.7(27.6-62.0)$ & Waitrose & 24 & $416 \pm 32(342-474)$ \\
\hline Waitrose & 24 & $38.6 \pm 7.0(27.0-57.0)$ & Tesco & 51 & $410 \pm 40(303-501)$ \\
\hline Tesco & 51 & $38.4 \pm 8.1(21.8-54.7)$ & Morrisons & 35 & $407 \pm 36(346-478)$ \\
\hline Aldi & 20 & $36.7 \pm 7.8(26.0-61.0)$ & Aldi & 20 & $403 \pm 45(273-475)$ \\
\hline Sainsbury's & 45 & $35.9 \pm 7.2(23.4-52.0)$ & Sainsbury's & 45 & $400 \pm 33(301-502)$ \\
\hline Lidl & 21 & $33.7 \pm 6.1(23.0-47.0)$ & McVitie's & 7 & $369 \pm 14(355-395)$ \\
\hline
\end{tabular}




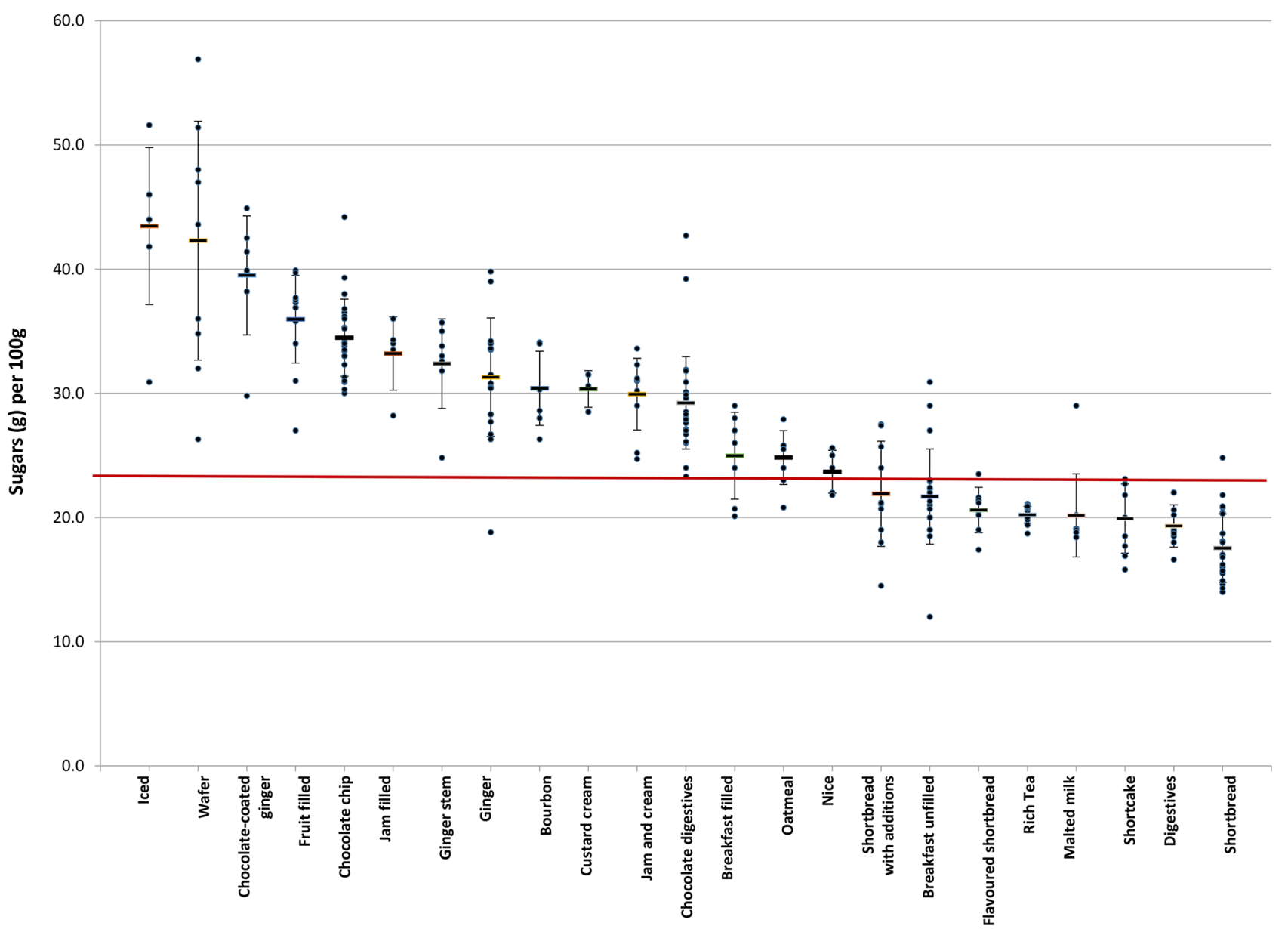

Figure 3 Sugar content in different biscuit categories (g/100g), red line denotes red (high) label criteria for sugar (>22.5 g).

with supermarket own label (32.8g vs $28.3 \mathrm{~g}, \mathrm{P}<0.001$ ). Seventy-four per cent of biscuits would receive a 'red' (high) label for sugar (>22.5 g/100g) (figure 3).

A total of 408 products provided nutrition information per suggested serving size, where the serving size was $\geq 10 \mathrm{~g}$ (table 7). The mean sugar content in biscuits was $6.2 \pm 3.7 \mathrm{~g} / \mathrm{serving}$. Breakfast biscuits with filling had the largest serving size, therefore the highest sugar content $(12.0 \pm 2.4 \mathrm{~g} / \mathrm{serving})$, followed by breakfast biscuits without filling $(10.2 \pm 2.1 \mathrm{~g})$.

On average, a biscuit serving (as set by the manufacturers) contains $21 \%$ of an adult's (30 g/day) and $33 \%$ of a 4-6years old child's $(19 \mathrm{~g} /$ day $)$ maximum recommended sugar intake.

Among the 29 breakfast biscuits (filled and unfilled), $59 \%$ contained more than a third of an adult's $(\geq 10 \mathrm{~g})$ maximum daily recommendation of sugar per serving; this is partly because one serving is $2-4$ biscuits.

\section{Energy}

Figure 4 and table 6 show the energy content in different categories of biscuits per $100 \mathrm{~g}$. The average energy content in biscuits was $484 \pm 38 \mathrm{kcal} / 100 \mathrm{~g}$. There was a large variation in energy content between different categories of biscuits and within the same category of biscuit ranging from 331 to $585 \mathrm{kcal} / 100 \mathrm{~g}$. On average, shortbread biscuits with additions $(528 \pm 18 \mathrm{kcal} / 100 \mathrm{~g})$ contained the highest amount of energy and fruit-filled biscuits $(391 \pm 11 \mathrm{kcal} / 100 \mathrm{~g})$ contained the lowest amount of energy.

The average energy content in biscuits per serving was $97 \pm 46 \mathrm{kcal}$ (table 7 ). Only one product exceeded the maximum calorie cap of $325 \mathrm{kcal}$ per serving.

Among the manufacturers with five or more products, the Fox's product range contained the highest average sugar content, $35.8 \pm 8.5 \mathrm{~g} / 100 \mathrm{~g}$, and Dr. Schar product range contained the highest average energy content, $512 \pm 10 \mathrm{kcal} / 100 \mathrm{~g}$ (table 8).

\section{DISCUSSION}

This research makes available important baseline data on the sugar and energy content of cakes and biscuits in the UK, for future evaluation of the recently launched sugar-reduction programme. This study also showed that the levels of sugar and energy in products can be reduced, since there was a large variation in sugar and energy content within the same category of cakes and biscuits. For instance, some manufacturers can produce chocolate cake bars with $22 \%$ fewer calories per $100 \mathrm{~g}$. Biscuits contain less sugar compared with cakes, but 
Table 6 Sugar and energy content in biscuits per $100 \mathrm{~g}$

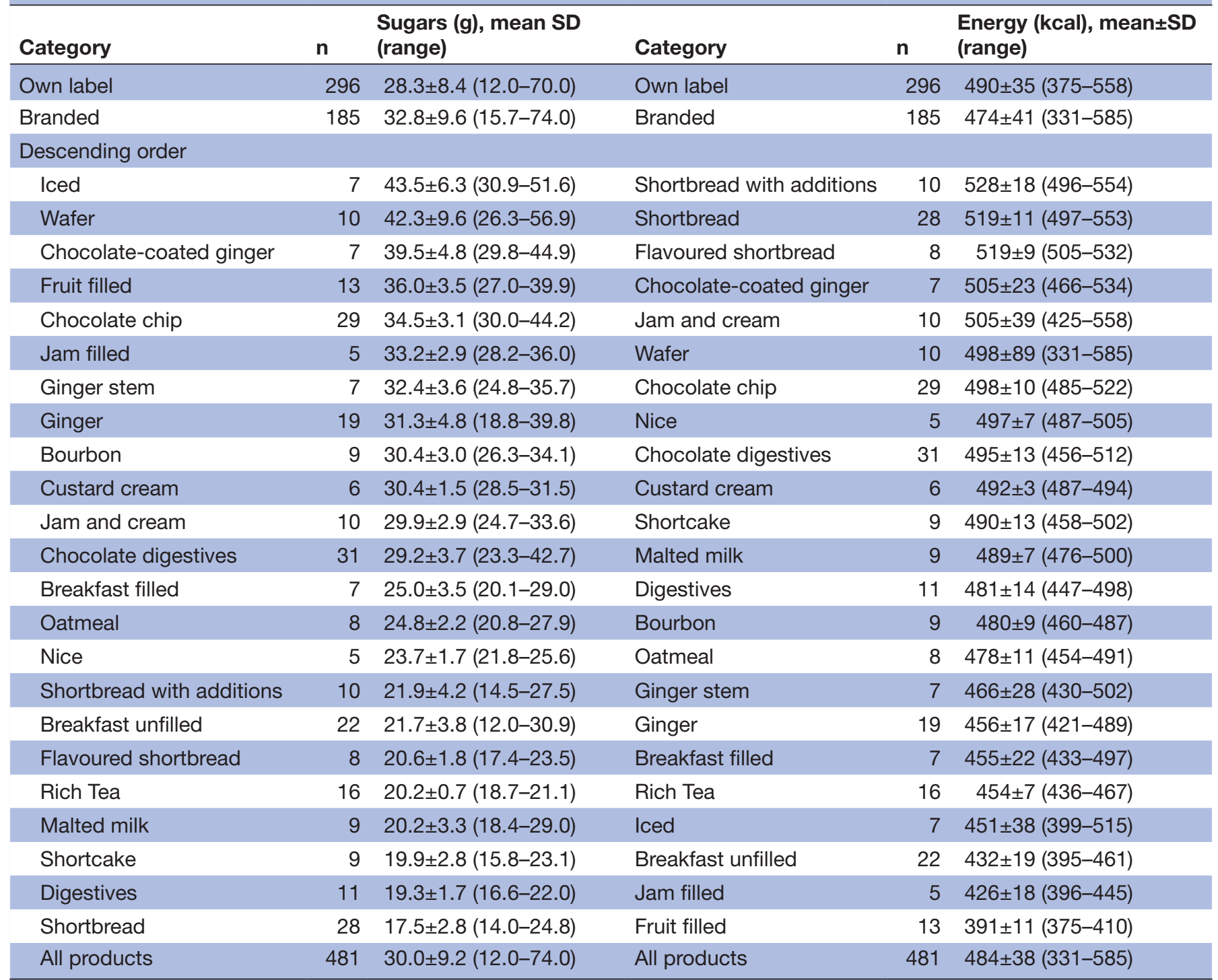

people often consume more than one serving (ie, more than one biscuit).

There is extensive evidence that consuming too much sugar and energy is a major contributor to obesity and dental caries. ${ }^{16}$ Hence, there is an urgent need to reduce the amount of sugar and energy consumed. The sugar and energy content in cakes and biscuits can be reduced through reformulation, that is, by gradually reducing the amount of sugar and total energy. ${ }^{30}$ Indeed, evidence from modelling studies suggests that sugar reformulation programmes can potentially reduce sugar intake and improve health outcomes. ${ }^{31-35}$

Studies show that biscuits can be reformulated to reduce sugar and energy content, for example, by using prebiotic fibre (fructo-oligosaccharide), ${ }^{36} 37$ acesulfame-K, polyols, ${ }^{38}{ }^{39}$ stevia, coffee silverskin ${ }^{40}$ and protein. ${ }^{37}$ The reformulated biscuits were acceptable in terms of eating quality, flavour, colour and improved nutritional value. ${ }^{363840}$ Similar studies have been carried out to produce reduced sugar and reduced energy cakes and muffins. ${ }^{41-45}$ Indeed, many consumers are increasingly interested in buying cakes made with alternatives to sugar $(\mathrm{eg}, \mathrm{xylitol}) .{ }^{46}$

Despite this, manufacturers have made little progress in reducing sugar in cakes and biscuits since $97 \%$ of cakes and $74 \%$ of biscuits would receive a 'red' (high) label for sugars per $100 \mathrm{~g}$ and only one in four cake launches featured low/no/reduced fat claims in 2013 and less than 1\% claimed to be low/no/reduced sugar. ${ }^{26}$

The industry should be encouraged to shift sales to new 'healthier' alternatives with significantly lower sugar and energy levels, since this will also help to achieve the necessary change in the SWA. However, for the full benefits of reformulation to be seen, it needs to permeate the entire cake and biscuit supply chain; and therefore argues against making new products with claims, for example, ' $x \%$ less fat/sugar'. Owing to the huge volume of standard popular cakes and biscuits consumed, even small reductions could 
Table 7 Sugar and energy content in biscuits per serving

\begin{tabular}{|c|c|c|c|c|c|}
\hline Category & $\mathbf{n}$ & $\begin{array}{l}\text { Sugars (g), mean } \pm S D \\
\text { (range) }\end{array}$ & Category & $\mathbf{n}$ & $\begin{array}{l}\text { Energy (kcal) mean } \pm \text { SD } \\
\text { (range) }\end{array}$ \\
\hline Own label & 247 & $5.6 \pm 3.7(1.9-35.9)$ & Own label & 247 & $93 \pm 45(38-385)$ \\
\hline Branded & 161 & $7.1 \pm 3.5(1.7-24.4)$ & Branded & 161 & $104 \pm 47(44-230)$ \\
\hline \multicolumn{6}{|l|}{ Descending order } \\
\hline Breakfast filled & 7 & $12.0 \pm 2.4(9.3-14.7)$ & Breakfast filled & 7 & $218 \pm 22(188-251)$ \\
\hline Breakfast unfilled & 22 & $10.2 \pm 2.1(4.5-14.5)$ & Breakfast unfilled & 22 & $202 \pm 21(161-228)$ \\
\hline Iced & 4 & $9.4 \pm 3.7(4.2-12.9)$ & Malted milk & 1 & $119 \pm 0$ \\
\hline Wafer & 6 & $8.7 \pm 0.8(7.2-9.4)$ & Ginger stem & 7 & $105 \pm 15(83-122)$ \\
\hline Chocolate-coated ginger & 7 & $7.4 \pm 1.9(4.8-10.0)$ & Shortbread & 24 & $97 \pm 24(54-182)$ \\
\hline Ginger stem & 7 & $7.4 \pm 1.5(4.7-9.1)$ & $\begin{array}{l}\text { Shortbread with } \\
\text { additions }\end{array}$ & 10 & $95 \pm 18(62-110)$ \\
\hline Jam filled & 5 & $6.1 \pm 0.4(5.6-6.8)$ & $\begin{array}{l}\text { Chocolate- } \\
\text { coated ginger }\end{array}$ & 7 & $94 \pm 21(67-123)$ \\
\hline Chocolate chip & 27 & $6.1 \pm 2.4(3.3-9.8)$ & Wafer & 6 & $93 \pm 35(49-137)$ \\
\hline Jam and cream & 10 & $5.2 \pm 1.5(3.9-9.0)$ & Iced & 4 & $89 \pm 26(52-112)$ \\
\hline Fruit filled & 13 & $5.1 \pm 1.5(3.4-7.8)$ & Chocolate chip & 27 & $88 \pm 33(50-131)$ \\
\hline Malted milk & 1 & $5.1 \pm 0.0$ & Jam and cream & 10 & $88 \pm 28(73-166)$ \\
\hline Chocolate digestives & 31 & $4.9 \pm 1.0(3.3-8.1)$ & $\begin{array}{l}\text { Chocolate } \\
\text { digestives }\end{array}$ & 31 & $83 \pm 11(52-124)$ \\
\hline Shortbread with additions & 10 & $3.9 \pm 1.0(2.5-5.3)$ & Jam filled & 5 & $79 \pm 6(74-89)$ \\
\hline Bourbon & 9 & $3.9 \pm 0.4(2.9-4.2)$ & Digestives & 11 & $72 \pm 7(62-85)$ \\
\hline Custard cream & 6 & $3.9 \pm 0.2(3.6-4.1)$ & Oatmeal & 6 & $71 \pm 2(69-74)$ \\
\hline Ginger & 15 & $3.7 \pm 1.2(2.6-7.6)$ & $\begin{array}{l}\text { Flavoured } \\
\text { shortbread }\end{array}$ & 8 & $69 \pm 17(53-103)$ \\
\hline Oatmeal & 6 & $3.6 \pm 0.3(3.2-3.9)$ & Custard cream & 6 & $64 \pm 3(62-69)$ \\
\hline Shortbread & 24 & $3.3 \pm 0.9(2.2-6.5)$ & Bourbon & 9 & $63 \pm 7(51-68)$ \\
\hline Digestives & 11 & $2.9 \pm 0.2(2.5-3.2)$ & Shortcake & 9 & $62 \pm 21(49-115)$ \\
\hline Flavoured shortbread & 8 & $2.7 \pm 0.6(2.1-3.5)$ & Fruit filled & 13 & $55 \pm 17(38-95)$ \\
\hline Shortcake & 9 & $2.5 \pm 1.0(1.8-5.0)$ & Ginger & 15 & $52 \pm 18(45-116)$ \\
\hline Rich Tea & 1 & $2.0 \pm 0.0$ & Rich Tea & 1 & $47 \pm 0$ \\
\hline All products & 408 & $6.2 \pm 3.7(1.7-35.9)$ & All products & 408 & $97 \pm 46(38-385)$ \\
\hline
\end{tabular}

have a significant impact on sugar and energy intake of the entire population. Reformulating in ways such as reducing sugar, replacing icing and buttercream with low-fat yoghurt in frosting and fillings, making cakes with fruit and vegetables (eg, carrot, beetroot) and biscuits with dried fruits. Alternatives with claims, even after several years on the market, generally only account for a small proportion of sales, and are unlikely to change sugar and energy intake of the entire population significantly. ${ }^{24}$

Some portion sizes are getting bigger and pose a greater challenge. ${ }^{47}$ Research shows that larger portion sizes result in more calories being consumed and it is estimated that if larger-sized portions were removed from the diet completely, this could reduce energy intake by up to $16 \% .^{48}$ Therefore, the cakes and biscuits sector need to reduce portion size of the large portions available. Furthermore, many sweet biscuits are often packaged in formats that encourage greater consumption. Some consumers limit how often they eat biscuits because it is easy to eat too many biscuits once the pack is opened. ${ }^{49}$ As such, packaging formats offering portion control would help. ${ }^{27}$ However, there is a lack of research on the threshold size for smaller portions, eg, the cut-off point where consumers will consume two portions instead of one. Public Health England has defined single-serve cakes as all cakes above $10 \mathrm{~g}$ or $\leq 150 \mathrm{~g}$ and biscuits as all products above $10 \mathrm{~g}$ or $\leq 80 \mathrm{~g}{ }^{24}$ The survey showed that not many products exceeded the maximum calorie cap of $325 \mathrm{kcal}$. This may suggest the calorie cap is more applicable to cakes and biscuits served in the out-of-home than the retail sector, or that the cap is not challenging enough.

Aside from reformulation and portion size restrictions, evidence shows that consumption of cakes and biscuits is influenced by in-store promotions. One in 


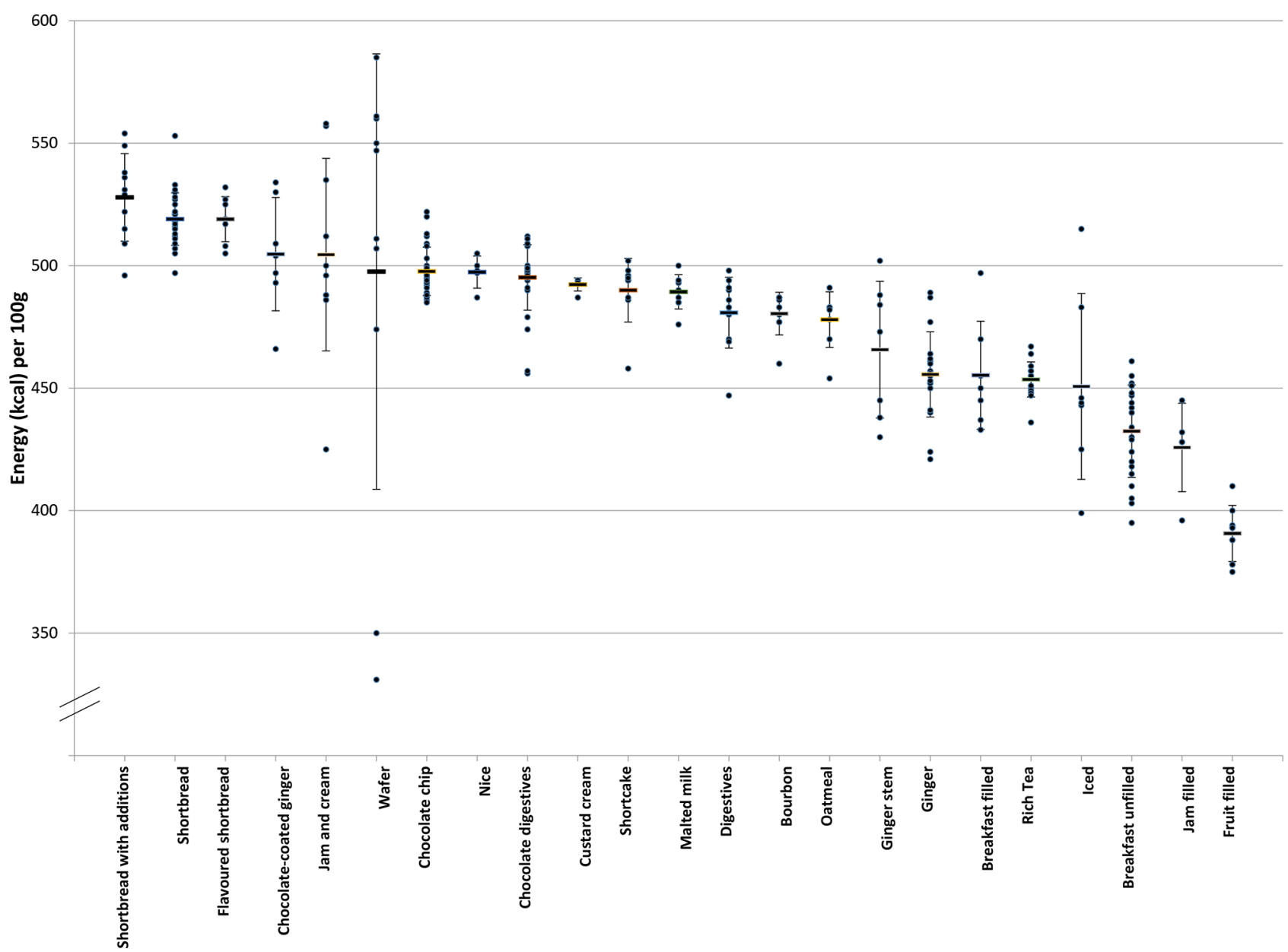

Figure 4 Energy content in different biscuit categories (kcal/100g).

three people stock up on cakes when on promotion. ${ }^{25}$ Therefore, reducing the level of promotion on cakes and biscuits is also necessary to reduce intake. ${ }^{30}$

\section{LIMITATIONS}

Our study was based on sugar and energy content data provided on cake and biscuit product packaging labels in store; hence, we relied on the accuracy of the data provided on the label. It is assumed that the manufacturers provide accurate and up to date information in line with regulations. However, further studies should include sugar and energy content determined through laboratory analysis to ensure greater accuracy and to achieve a better understanding of the types of sugars used. This is because we were unable to distinguish if sugars labelled on the packaging are all free sugars or if some are from milk, fruits and vegetables.

This study did not include Christmas cakes and biscuits which are typically more indulgent; therefore, depending on the time of year, results may be slightly different. Also, this survey did not include in-store bakery items as the nutrition labelling was not available on pack for these products, which may have affected the results.

Furthermore, this study did not analyse the fat and saturated fat contents of the cakes and biscuits, however total energy content was included, which would encompass the amount of energy coming from fat and therefore any potential future reductions in the amount of total energy can be achieved from reductions in fat and/or sugar.

Our data do not include sugar and energy content of cakes and biscuits in the out-of-home sector; this is due to the lack of publicly available data. Future studies should endeavour to include this type of data too, especially as purchases of these products have increased in recent years, and food eaten out of the home now accounts for a growing proportion of the total amount of food eaten. More than $25 \%$ of adults and one-fifth of children buy and consume food out of home/on the go at least once a week. ${ }^{50}$

Nevertheless, the results of this study document the sugar and energy content of cakes and biscuits sold in the UK, providing baseline data to evaluate public health interventions such as the sugar-reduction programme and potentially incentivise the cakes and biscuits industry to reformulate their products.

\section{CONCLUSION}

This research provides baseline data of the cakes and biscuits market in the UK for evaluation of the recently launched sugar-reduction programme. The study also 
Table 8 Sugar and energy content in biscuits by manufacturer per $100 \mathrm{~g}$

\begin{tabular}{|c|c|c|c|c|c|}
\hline Manufacturer & $\mathbf{n}$ & $\begin{array}{l}\text { Sugars (g), mean } \pm \text { SD } \\
\text { (range) }\end{array}$ & Manufacturer & $\mathbf{n}$ & $\begin{array}{l}\text { Energy (kcal), mean } \pm \text { SD } \\
\text { (range) }\end{array}$ \\
\hline Fox's & 27 & $35.8 \pm 8.5(19.1-49.0)$ & Dr. Schar & 5 & $512 \pm 10(500-523)$ \\
\hline Bahlsen & 11 & $35.4 \pm 6.0(23.0-43.0)$ & Bahlsen & 11 & $511 \pm 31(445-561)$ \\
\hline Burton's Biscuit Co. & 12 & $34.3 \pm 3.6(28.2-41.3)$ & Waitrose & 23 & $507 \pm 33(378-534)$ \\
\hline Mondelez International & 33 & $32.3 \pm 8.8(19.0-49.9)$ & Marks \& Spencer & 68 & $504 \pm 29(430-558)$ \\
\hline McVitie's & 42 & $32.1 \pm 8.4(16.6-51.6)$ & Asda & 36 & $492 \pm 32(375-548)$ \\
\hline Dr. Schar & 5 & $31.6 \pm 1.7(29.0-33.0)$ & Fox's & 27 & $488 \pm 28(441-527)$ \\
\hline Aldi & 28 & $30.3 \pm 7.9(12.0-42.0)$ & Lidl & 19 & $487 \pm 31(418-535)$ \\
\hline Morrisons & 27 & $30.1 \pm 11.1(15.5-61.6)$ & Morrisons & 27 & $487 \pm 36(379-531)$ \\
\hline Tesco & 31 & $30.0 \pm 10.8(14.6-70.0)$ & Sainsbury's & 51 & $486 \pm 36(378-553)$ \\
\hline Border Biscuits Ltd & 7 & $29.6 \pm 8.6(16.4-44.9)$ & Tesco & 31 & $482 \pm 33(388-539)$ \\
\hline Lidl & 19 & $29.5 \pm 6.6(16.0-39.0)$ & Mondelez International & 33 & $475 \pm 37(395-539)$ \\
\hline Marks \& Spencer & 68 & $28.7 \pm 8.9(14.3-48.9)$ & Aldi & 28 & $474 \pm 34(382-514)$ \\
\hline Waitrose & 23 & $27.9 \pm 7.6(17.9-46.2)$ & Co-operative & 13 & $472 \pm 41(380-525)$ \\
\hline Asda & 36 & $27.6 \pm 7.3(14.0-45.0)$ & Burton's Biscuit Co. & 12 & $469 \pm 35(425-512)$ \\
\hline Kellogg's & 6 & $26.0 \pm 5.8(19.0-32.0)$ & McVitie's & 42 & $462 \pm 39(393-516)$ \\
\hline Sainsbury's & 51 & $25.7 \pm 6.5(14.0-47.0)$ & Weight Watchers & 5 & $461 \pm 18(438-483)$ \\
\hline Weight Watchers & 5 & $25.2 \pm 4.9(17.1-30.0)$ & Border Biscuits Ltd & 7 & $460 \pm 34(400-505)$ \\
\hline Co-operative & 13 & $24.5 \pm 6.4(14.9-34.0)$ & Nairn's & 8 & $457 \pm 12(438-470)$ \\
\hline Nairn's & 8 & $18.7 \pm 2.6(15.7-22.7)$ & Kellogg's & 6 & $429 \pm 31(379-470)$ \\
\hline
\end{tabular}

showed that reduction in the sugar and energy content of cakes and biscuits is possible because there was a large variation in sugar and energy content not only between different categories of cakes and biscuits but also within the same category. A reduction in sugar and energy content and overall cake and biscuit consumption can help reduce overall sugar and energy intake in the UK and thus help to reduce the risk of obesity and dental caries.

Contributors $\mathrm{KMH}$ conducted the research. $\mathrm{KMH}$ and FJH analysed the data. SAA helped check the data. KMH wrote the first draft of the manuscript and all authors contributed to the interpretation of the results and revision of the manuscript, and approved the final manuscript.

Funding The authors have not declared a specific grant for this research from any funding agency in the public, commercial or not-for-profit sectors.

Competing interests KMH and SAA are employees of Consensus Action on Salt, Sugar and Health (CASSH), a non-profit charitable organisation. FJH is a member of Action on Salt and its international branch World Action on Salt \& Health (WASH) and does not receive any financial support from Action on Salt or WASH. GAM is Chairman of Blood Pressure UK (BPUK), Chairman of CASSH and Chairman of WASH. BPUK, CASSH and WASH are non-profit charitable organisations.

Patient consent Not required.

Provenance and peer review Not commissioned; externally peer reviewed.

Data sharing statement The sugar and calorie information of each product included will be available on emailing the corresponding author.

Open access This is an open access article distributed in accordance with the Creative Commons Attribution Non Commercial (CC BY-NC 4.0) license, which permits others to distribute, remix, adapt, build upon this work non-commercially, and license their derivative works on different terms, provided the original work is properly cited and the use is non-commercial. See: http://creativecommons.org/ licenses/by-nc/4.0/ (c) Article author(s) (or their employer(s) unless otherwise stated in the text of the article) 2018. All rights reserved. No commercial use is permitted unless otherwise expressly granted.

\section{REFERENCES}

1. SACN. Carbohydrates and health. 2015. https://www.gov.uk/ government/uploads/system/uploads/attachment_data/file/445503/ SACN_Carbohydrates_and_Health.pdf

2. Romaguera D, Norat T, Wark PA, et al. Consumption of sweet beverages and type 2 diabetes incidence in European adults: results from EPIC-InterAct. Diabetologia 2013;56:1520-30.

3. de Koning L, Malik VS, Rimm EB, et al. Sugar-sweetened and artificially sweetened beverage consumption and risk of type 2 diabetes in men. Am J Clin Nutr 2011;93:1321-7.

4. Maki KC, Phillips AK. Dietary substitutions for refined carbohydrate that show promise for reducing risk of type 2 diabetes in men and women. J Nutr 2015;145:159S-63.

5. Te Morenga L, Mallard S, Mann J. Dietary sugars and body weight: systematic review and meta-analyses of randomised controlled trials and cohort studies. BMJ 2012;346:e7492.

6. Johnson RK, Appel LJ, Brands M, et al. Dietary sugars intake and cardiovascular health: a scientific statement from the American Heart Association. Circulation 2009;120:1011-20.

7. Moynihan PJ, Kelly SA. Effect on caries of restricting sugars intake: systematic review to inform WHO guidelines. J Dent Res 2014;93:8-18.

8. Public Health England. UK and Ireland prevalence and trends. 2013. https://www.noo.org.uk/NOO_about_obesity/adult_obesity/UK_ prevalence_and_trends (accessed 2 Jul 2015).

9. HSCIC. Statistics on obesity, physical activity and diet: England 2014. 2014. http://www.hscic.gov.uk/catalogue/PUB13648/Obesphys-acti-diet-eng-2014-rep.pdf (accessed 2 Jul 2015).

10. Public Health England. Adult obesity and type 2 diabetes. 2014. https://www.gov.uk/government/uploads/system/uploads/ attachment_data/file/338934/Adult_obesity_and_type_2_diabetes_. pdf (accessed 2 Jul 2015).

11. HSCIC. National diabetes audit. 2008. http://www.hscic.gov. uk/catalogue/PUB02580/nati-diab-audi-07-08-exec-summ.pdf (accessed Jul 2015) 
12. Public Health England. National Dental Epidemiology Programme for England: oral health survey of five-year-old children 2012. A report on the prevalence and severity of dental decay. 2012. http://www. nwph.net/dentalhealth/Oral\%20Health\%205yr\%20old\%20children\% 202012\%20final\%20report\%20gateway\%20approved.pdf (accessed 2 Dec 2015).

13. Public Health England. Dental public health epidemiology programme. Oral health survey of three-year-old children 2013. A report on the prevalence and severity of dental decay. $2014 \mathrm{http}: / /$ www.nwph.net/dentalhealth/reports/DPHEP\%20for\%20England\% 20OH\%20Survey\%203yr\%202013\%20Report.pdf (accessed 2 Dec 2015).

14. NHS. Executive summary: adult dental health survey. 2009. http:// www.hscic.gov.uk/catalogue/PUB01086/adul-dent-heal-surv-summthem-exec-2009-rep2.pdf (accessed 2 Dec 2015).

15. Public Health England. Sugar reduction responding to the challenge. 2014. 1 Jun 2014. https://www.gov.uk/government/uploads/ system/uploads/attachment_data/file/324043/Sugar_Reduction_ Responding_to_the_Challenge_26_June.pdf

16. Public Health England. Why 5\%?. 2015. https://www.gov.uk/ government/uploads/system/uploads/attachment_data/file/446010/ Why_5_-_The_Science_Behind_SACN.pdf

17. Public Health England. NDNS: results from years 5 and 6 (combined). 2016. 2 Jun 2016. https://www.gov.uk/government/statistics/ndnsresults-from-years-5-and-6-combined

18. Rennie KL, Jebb SA, Wright A, et al. Secular trends in underreporting in young people. Br J Nutr 2005;93:241-7.

19. Campbell R, Tasevska N, Jackson KG, et al. Association between urinary biomarkers of total sugars intake and measures of obesity in a cross-sectional study. PLoS One 2017;12:e0179508.

20. Hebert JR, Ebbeling CB, Matthews CE, et al. Systematic errors in middle-aged women's estimates of energy intake: comparing three self-report measures to total energy expenditure from doubly labeled water. Ann Epidemiol 2002;12:577-86.

21. Lara JJ, Scott JA, Lean ME. Intentional mis-reporting of food consumption and its relationship with body mass index and psychological scores in women. J Hum Nutr Diet 2004;17:209-18.

22. Rennie KL, Coward A, Jebb SA. Estimating under-reporting of energy intake in dietary surveys using an individualised method. Br J Nutr 2007;97:1169-76.

23. Archer E, Hand GA, Blair SN. Validity of U.S. nutritional surveillance:National Health and Nutrition Examination Survey caloric energy intake data, 1971-2010. PLoS One 2013;8:e76632.

24. Public Health England. Sugar reduction: achieving the $20 \% .2017$. https://www.gov.uk/government/publications/sugar-reductionachieving-the-20

25. Mintel. Cakes and cake bars UK. 2014. (June 2014).

26. Mintel. Cakes market trends: small cakes overtake large cakes. 2013. 2 Jun 2016. http://www.mintel.com/press-centre/food-and-drink/ukcakes-market-trend

27. Mintel. Biscuits, cookies and crackers - UK - April 2015. 2015 http:// academic.mintel.com/display/715858/?_cc $=1$

28. Kantar-Worldpanel. Grocery market share - Kantar Worldpanel. 2016 http://www.kantarworldpanel.com/en/grocery-market-share/greatbritain (accessed 30 Apr 2016).

29. Department-of-Health. Guide to creating a Front of Pack (FoP) nutrition label for pre-packed products sold through retail outlets. 2016 https://www.food.gov.uk/sites/default/files/multimedia/pdfs/ pdf-ni/fop-guidance.pdf (accessed 1 July 2017).

30. Public Health England. Sugar reduction the evidence for action. 2015 https://www.gov.uk/government/uploads/system/uploads/ attachment_data/file/470179/Sugar_reduction_The_evidence_for_ action.pdf (accessed 2 October 2015).

31. Tedstone A, Targett V, Allen R. Sugar Reduction: The evidence for action Annexe 5: Food supply. 2015 https://www.gov.uk/government/
uploads/system/uploads/attachment_data/file/470176/Annexe_5._ Food_Supply.pdf (accessed 2 Jan 2017).

32. Combris P, Goglia R, Henini M, et al. Improvement of the nutritional quality of foods as a public health tool. Public Health 2011;125:717-24.

33. Leroy P, Réquillart V, Soler LG, et al. An assessment of the potential health impacts of food reformulation. Eur J Clin Nutr 2016;70:694-9.

34. Roodenburg AJ, Schlatmann A, Dötsch-Klerk M, et al. Potential effects of nutrient profiles on nutrient intakes in the Netherlands, Greece, Spain, USA, Israel, China and South-Africa. PLoS One 2011;6:e14721

35. Roodenburg AJ, van Ballegooijen AJ, Dötsch-Klerk M, et al. Modelling of usual nutrient intakes: potential impact of the choices programme on nutrient intakes in young dutch adults. PLoS One 2013;8:e72378.

36. Boobier WJ, Baker JS, Davies B. Development of a healthy biscuit: an alternative approach to biscuit manufacture. Nutr J 2006;5:7.

37. Gallagher E, O'Brien CM, Scannell AGM, et al. Use of response surface methodology to produce functional short dough biscuits. $J$ Food Eng 2003;56:269-71.

38. Zoulias El, Piknis S, Oreopoulou V. Effect of sugar replacement by polyols and acesulfame-K on properties of low-fat cookies. J Sci Food Agric 2000;80:2049-56.

39. Laguna L, Vallons KJR, Jurgens A, et al. Understanding the Effect of Sugar and Sugar Replacement in Short Dough Biscuits. Food Bioproc Tech 2013;6:3143-54.

40. Garcia-Serna E, Martinez-Saez N, Mesias M, et al. Use of Coffee Silverskin and Stevia to Improve the Formulation of Biscuits. Pol J Food Nutr Sci 2014;64.

41. Psimouli V, Oreopoulou V. The effect of alternative sweeteners on batter rheology and cake properties. J Sci Food Agric 2012;92:99-105.

42. Struck S, Gundel L, Zahn S, et al. Fiber enriched reduced sugar muffins made from iso-viscous batters. LWT - Food Science and Technology 2016;65:32-8.

43. Martínez-Cervera S, Sanz T, Salvador A, et al. Rheological, textural and sensorial properties of low-sucrose muffins reformulated with sucralose/polydextrose. LWT - Food Science and Technology 2012;45:213-20.

44. Masooi FA, Sharma B, Chauhan GS. Use of apple pomace as a source of dietary fiber in cakes. Plant Foods Hum Nutr 2002;57:121-8.

45. Martínez-Cervera S, Salvador A, Sanz T. Comparison of different polyols as total sucrose replacers in muffins: Thermal, rheological, texture and acceptability properties. Food Hydrocoll 2014;35:1-8.

46. Mintel. National afternoon tea week: Young brits shun the traditional cuppa, but cake sales are yet to crumble. $2016 \mathrm{http}: / / \mathrm{www}$.mintel. $\mathrm{com} /$ press-centre/food-and-drink/national-afternoon-tea-weekyoung-brits-shun-the-traditional-cuppa-but-cake-sales-are-yet-tocrumble

47. Food Standards Agency. The role of portion sizes in our diet. 2008 http://webarchive.nationalarchives.gov.uk/20120206100416/http:// food.gov.uk/news/newsarchive/2008/jun/portionsize

48. Hollands GJ, Shemilt I, Marteau TM, et al. Portion, package or tableware size for changing selection and consumption of food, alcohol and tobacco. Cochrane Database Syst Rev 2015:CD011045.

49. Mintel. Biscuits, cookies and crackers - UK - consumer market research report - company profiles - market trends - 2015. 2 Jun 2016. 2016. http://store.mintel.com/biscuits-cookies-and-crackersuk-april-2015

50. Public Health England. Health matters: obesity and the food environment. https://www.gov.uk/government/publications/healthmatters-obesity-and-the-food-environment/health-matters-obesityand-the-food-environment-2 